\section{7. 省エネルギー時代と獣医師の対応}

読売新聞 4 月 21 日の社説は「米の新エネルギー政策 と日本」と題して論説を発表した。 その内容はわれわれ にとって実に示唆にとんだものである.これを以下紹介 して獣医師としての対応は如何にあるべきかを考党てみ たい.「カーター米大統領は 18 日夜(筆者註 4 月 18 日），全国民にテレビを通じて，迫りくるエネルギー危 機を訴え, 節約による石油の輸入依存度引き下げの緊急 性を説いた，20日にェネルギー教書を議会に送る前に， 国民の理解と協力を求めたもので, 豊富で安いエネルギ 一の大量消費に支えられてきたアメリカ生活様式そのも のへ，大統領の指導力をかけて挑戦したものといえる. わが国は米国以上に省エネルギーを推進しなければなら ないのに，立ち遅れている，政府はこれを機会にわが 国独自のエネルギー政策樹立についての国民的合意形成 に努力すべきである．世界が米国の新しいエネルギー政 策に重大な関心を抱くのは, 切実な理由があるからであ る. それは迫りくるエネルギー危機に自由世界が正しく 対応し，これを回避するには，米国の政策動向がカギを 握っていると考えるからだ. 経済協力開発機構 (OE C D) は 1985 年ごろになると, 世界の石油需要が石油輸 出国機構(OP E C) の生産量を上迴り, 物理的な石油不 足時代に入ると予測している. 新政策の採用に踏み切る について参考にされた米中央情報局（C I A）の報告 も，泳同じ見方をとっている，その場合，石油価格は さらに高いものになるだけでなく，米国，欧洲諸国，日 本が，中東石油の争奪をめぐって対立することが予想さ れる. (中略)

\section{石油不足時代を回避する道}

新しいエネルギー政策は，エネルギー高価格政策の導 入と石炭の増産を柱として打り，(中略）エネルギー高 価格政策の重点は，交通部門に沶かれ，ガりリン消費税 の引き上げと，燃料効率の良い車の生産奨励が手段とな っている. エネルギー消費の 4 分の 1 がこの部門で行な われていることを考えると，適切な政策といえる：ま た，これとほぼ同じ比重の消費をしている民需部門での 節約には, 民間住宅の $90 \%$ に, 冷暖房効率を高める断 熱設備をつけるといら方針が出された. ガソリンを湯水 のように使う大型車や冷暖房完備の住宅は, アメリカ的 生活様式の根幹をなすもので, カーター大統領は, まさ
日本獣医師会会長 中 村寛

に生活様式そのものの変革を訴えたのである.（中略）

\section{わが国も国民的合意の形成を}

『日本には石油もないが, 知恵もないのか』と, 国際 社会でいわれている。米国に次ぐ石油輸入国，しかも 国産がゼロに近い国なのに，省エネルギーは掛け声だけ で，実効はあがっていない，そのことへの皮肉である。

（中略）いま政府は，総合エネルギー政策の大がかりな 見直し作業をしている. 50 年 12 月に決めた政策の基本 方向は正しいとしても, 将来の需給見通しは甘いるの で，大幅な修正が必要である. その前提となるるのは， エネルギー危機への正しい認識を広く国民に知らせるこ とであろう.（中略）しかし，全体としてのエネルギー 危機への認識は, 政府, 民間とも，一部識者の間でのみ 深まり，国民的広がりに欠けているのが現状である. エ ネルギー問題の解決には，国民的合意の成立が不可欠の 条件で, この点について, 政府は強力な手を打つべきで ある.このような合意の上に, 開発と節約に同等の重要 性を与え，開発に必要な膨大な資金調達の問題を考える と同時に，これと並行して，省エネルギー政策を充実， 前進させなければならない，米国の新エネルギー政策 が, 節約を手段にして, エネルギー需要の伸びを落とす ことを眼目にしていることは，大いに参考になる。わが 国の省エネルギー政策に欠けているものは, 価格メカニ ズムの積極的活用と法的な規制の 2 点である. 自発的な 協力の呼びかけには限度がある. 2 つとも国民に儀牲を 求めるものだが，エネルギー危機を避けるための代価と 考觉なければならない。」一長い引用になったが内容の ある論説である.

昭和 48 年のエネルギー危機には, 通産省は =石油消 費節約令:を出して「この冬は閣議もオーバーを着てや ります」と当時の中篔根通産大臣は大い張り切ったが 現状はどうか.「ノドもと過ぎれば熱さ忘れる」はわが 国民の「熱し易く椧め易い」国民性を如実に表現してい るがェネルギー危機はそんななまやさしいるのではな い. 現在のエネルギー危機の実体は, 昭和 48 年のエネ ルギー危機の実体と本質的には何らかわっていないので めるが読売の社説も指摘するように，国民の対応は全く ゼロに近い.オールヒーティングの住宅では 4 日間に $500 し$ の石油を消費するといらが，こんな家がどんどん 新築されている.ところが若しこのような家が日本の住 宅の多くに採用されたとしたら石油を一体どうするかと

日獣会誌 $30 \quad 353 \sim 366 \quad$ (1977) $-353-$ 
なると人タば輸入するさこといら以外何も知らない。 また，若い人々は競って自分の車を大型車に買い換光る のが目下の流行だという.

\section{何故, わが国で省エネルギーが育たないのか}

このことに対し法政大学社会工学専攻の力石定一教授 は「現代の工業文明が，環境の危機に战ちこんだのは， 根本的には，『技術の選択』を詥ったことにある. 現代 技術は，物理学と化学の法則だけを組み合わせて，便利 さとスピードと省力化を『深追い』し，生態学の法則を 無視してきた.」(世界 5 月号, 省エネルギーのための提 言）ことにあると指摘し，これを是正する道は「物理学 と化学と生態学の 3 つの法則を最高に組み合わせ, 生態 学的に健全なものに向って，『技術の選択』を变更して いくことが重要である」と提言している，農業部門では 「農業では, 化学肥料と農薬の使用に対して高い環境污 染料を課し，ここから人糞を堆肥化するコンポスト・ト イレット（スカンジナビアで市販され，日本でもテスト がはじまっている）の設置に対して補助金を出す．畜翼 をコンポストしたものに対しても, 品質のよいものに補 助金を出すといった政策をとるべきだ. これ㞦よって化 学肥料と農業生産のためのエネルギー消費量を大幅に削 減することができよう，混作を奨励すれば，天敵の作用 が増えるし，輪作をすれば，畑のときに土壌に逃げた害 虫は，田んぼにして水をはられると窒息死するので，農 薬使用量はずっと減るだろら．以上のようにすれば，化 学物質の使用量が減り, 不必要になった化学工場も間引 いてゆけば，近海の水がきれいになる，その結果放牧型 の栽培漁業をさかんにすることができれば，遠洋漁業に 伴ら輸送エネルギー消費を大きく削減できるわけであ る.」(前揭誌)とすることを真剣に考穴なければならな いとも指摘している.

このように識者の熱心な指摘・提言にもかかわらず何 故, わが国で省エネルギーの常識が育たないのか。これ は国をあげての高度経済成長の悪夢がいまだにさめない ことにその原因があるのである，私がたびたび本稿で取 りあげてきた畜産物の安全性確保の問題も，この高度成 長の流孔としての大型畜産に和ける構造上の問題が解消 しない限り, 根本的な解決はあり得ないと断言してはば からない，すなわち，日本経済の構造上の問題点の解 消，国民の「生きる」ことの意識の改革，強力な法的対 応，行政の根本的大転換等々が省エネルギー政策の重要 な柱として強力に実行に移されなければならないのであ るが，国民の多くは事の重要性についてあまりにも認識 が稀薄である.

\section{省エネルギーと亩産・獣医師の対応}

本来農業生産は自然の循環系を合理化したものと理解
され，実行されてきたそそれが空中窒素の固定による㗧 素肥料の工業化ととるに農業生産は飛躍的に増大した が, いっぽう二農業は石油を喰う産業ことして大きく変 貌してきた。例を「わが国の水稲のエネルギー支出」に ついてみると，（千キロカロリー/ヘクタール）とエネ ルギー収入/支出比は 1950 年では 5.685 が 1960 年に は $12.990,1970$ 年には 28.416 と年々大幅に増大して いるのである，畜産についても同じで，例を牛肉につい てみると, 牛肉の形でのエネルギー収入1カロリーあた りのエネルギー支出は 15 カロリーである. と計算され るというのである.すなわち農業でも, 畜産でも, 機械 化による労働の合理化とか省力化, または化学肥料の増 施, 農薬の大量使用といったような, いわゆる農業の近 代化といら名によって, 恐しいばかりの石油エネルギー が消費されているのである，そして最近では畜産物の生 産だけではなく，その翼尿の処理にまで石油エネルギー が大量に使用されるようになった。

最近のわが国の飼料の実質自給率は $20 \%$ といわれて いるが，残りの $80 \%$ はすべて外国からの輸入である. 輸入には船が使用されるが，この船がまた大きく石油エ ネルギーを喰らのである.こうしてみてくると，わが国 に括ける畜産は省エネルギーの立場から考光るとき，そ れはまったく不経済な産業といらことになるのである. 何故, この不経済な畜産をわが国でやらなければならな いのか一一いらのは唯一つ，＝畜産物は国民の食糧で あるこがためである，然し，昨今のように世界的に石油 資源が欠乏し，省エネルギーの今日，それだけでは畜産 の存立の意義は完全とはい党ないのである.というの は，それは金ではなく，石油といら物が無くなるとい う。まことにどらにもならない現実だからである。昔か ら二無い袖はふれない:ということがあるが，ここで， ぞうしてもやらねばならないことは畜産の構造改革であ る.

ヨーロッパのある国では $50 \%$ の飼料を自給しない農 家には畜産援助の手はさしのべないという，また，ある 国では乳牛 10 頭までは一番多く，それ以上になると一 頭当りの国の補助金は大きく減額されるという。しかる に, わが国では酪農団地の造成には, 国・県・市町村の 補助金が，合せて $66 \%$ もつくという.1農家当りにす ると実に数千万円の補助額になるのである. そして，こ のため附近の堅実な 10 頭以下の（それは補助金のない 自立・模範農家である) 複合酪農家は年々減少するとい らのである. 省エネルギーの今日, 食糧自給が大きく叫 ばれている今日，＝何と馬鹿なことが、といっても現害 に全国各地にこのことが畜産振興の大きな柱として大々 的に行なわれているのである. この反面, 秋田県仁賀保町 農協では, 各農家が「鷄 10 羽, 豚 1 頭」を飼育しょう とする実践活動が，千葉県の三芳村では「庭先養鷂」が 
活発に実行されているという.

国が県が，食糧自給の本質を，省エネルギーの現実を 全く忘れているというのか, 農家がその本質を充分認識 しているといらのか，私は，それをここで問抢うとして いるのではない，ただ，そのいずれの場合にも獣医師が そこに介在しているのであろらと想像するのであるが， 何故, 獣医師個々が，その現実認識において，こうも差 があるのかといらことを問拈らとしているのである.

日本全獣医師長年の悲願であり私ほか執行部, 関係者 が命をはって努力して参った獣医学教育の 6 年制実施の ための獣医師法一部改正は，よほどのハプニングがない 限り本稿が印刷される頃には完了していることと思われ るが，問題はその内容である．真に年限延長の意識を充
足した獣医学教育が実現しなければ全く意義のないこと はしばしば論説において強調したところである.すなわ ち獣医学教育の 6 年制実現の目的は, 単に 2 力年の年限 を延長することではなく，より高度の獣医師を湌成する ことにあるが，このことは決して専門馬鹿を作ることで はない, 昨今の獣医師の博土指向ブーム(?), 獣医学の ミクロ化傾向を決して悪いというのではないが,ただ, 状 沉がどう変化しょうと, 畜産の現状を正確に把握して, 食糧の戦略化時代，省エネルギーのきびしいこの時代に 対応すると同時に更に難関を切り拓いて事態の改善をは かることが科学技術者としての責務であると信ずる.

(つづく)

\section{獣 医 師 法一部 改 正, 国 会成 立 獣医学教育修業年限延長いよいよ実現へ}

\section{獣医師法の一部を改正する法律（法律第 47 号） (農林省)}

獣医師が具有すべき知識および技能の水準を高め，か つ, これが多様化することが要請されている現状にかん がみ，獣医師の資質の向上を図るため，獣医師国家試験 の受験資格を, 大学に执いて獣医学を正規の課程を修め て卒業し, かつ大学院に拉いて獣医学の修士の課題を修 了した者に引き上げることとした.

（官報告示 昭和52年 5 月 27 日，第 15111 号による）

獣医師法の一部を改正する法律をここに公布する.

御名御覓

昭和 52 年 5 月 27 日

法律第 47 号

内閣総理大臣 福田越夫

\section{獣医師法の一部を改正する法律}

獣医師法（昭和 24 年法律第 186 号）の一部を次のよ らに改正する.

第 12 条第 1 号を次のように改める.

1 学校教育法（昭和 22 年法律第 26 号）に基つく 大学(短期大学を除く.) に抌いて獣医学の正規の課程を 修めて卒業し, かつ, 同法に基づく大学院において獣医 学の修士の課程を修了した者

附則第 16 項中「(昭和 22 年法律第 26 号)」を削る. 附 則

(施行期日)

1 この法律は, 昭和 53 年 4 月 1 日から施行する. (経過措置)

2 次の各号の 1 に該当する者は, 改正後の第 12 条の
規定にかかわらず，獣医師国家試験を受けることがで きる.

1 この法律の施行の際現に改正前の第 12 条各号 の 1 に該当する者

2 この法律の施行の日（以下「施行日」といら.） 前に改正前の第 12 条第 1 号の大学に在学し, 施 行日以後に改正前の同号に規定する要件に該当す ることとなった者（施行日以後に改正後の同号の 大学に新規に入学してこれを卒業することによ り，改正前の同号に規定する要件に該当すること となった者を除く.)

3 外国の獣医学校を卒業し，または外国で獣医師の免 許を得た者に関する第 12 条第 2 号の規定の適用につい ては，施行日以後 5 年間は，同号中「前号に揭げる 者」とあるのは,「獣医師法の一部を改正する法律 （昭和 52 年法律第 47 号）による改正前の獣医師法 第 12 条第 1 号に揭げる者」とする.

\section{農林大臣臨時代理}

国務大臣 長谷川四郎

内閣総理大臣 福田 趣夫

\section{獣医師法の一部を改正する法律案に対する附帯決議 衆議院農林水産委員会 昭和 52 年 5 月 12 日}

政府は，本法の施行にあたり，左記事項の実現に努め るべきである.

記

1. 6 年制獣医学教育の実施にあたっては, 学部 4 年と 大学院修士課程 2 年を通じて効果的な一貫教育が行兄 